\title{
Autologous serum eyedrops for dry eyes and epithelial defects: clinical and in vitro toxicity studies
}

\author{
Alexander C Poon, Gerd Geerling, John K G Dart, Graham E Fraenkel, Julie T Daniels
}

\begin{abstract}
Backgroundlaims-Autologous serum drops have been reported to be beneficial in keratoconjunctivitis sicca (KCS) and persistent epithelial defects (PED). A clinical pilot study was carried out to examine these potential uses and in vitro toxicity testing on corneal epithelial cell cultures was performed to compare the effect of serum drops with unpreserved hypromellose (hydroxypropylmethylcellulose $0.3 \%$ ).

Methods-Patients with KCS and PED, unresponsive to conventional treatment were recruited. Patients were examined before treatment, at 1 and 2 weeks after initiation, and then 2 weekly until treatment ceased. Symptoms were assessed at each visit. Clinical examination included Schirmer's test without anaesthesia, rose bengal staining, and fluorescein staining. Epithelial defects were measured with the slit beam. In the laboratory, cultured human corneal epithelial cells were exposed to serum drops and hypromellose, and their viability evaluated with fluorescent viability staining (Calcein AM ethidium homodimer) and an ATP assay.
\end{abstract}

Results-Autologous serum was used in 15 eyes of 13 patients with PED and 11 eyes of nine patients with KCS. In two patients serum drops were started after penetrating keratoplasty (PK). The PKs were performed for perforations secondary to PEDs. Of the 15 eyes with PED, nine healed at a mean of 29 days and six failed. The mean duration of PED before the use of serum drops was 48.2 days. Of the 11 eyes with KCS, six had improved subjective scores and fluorescein scores, and five had improved rose bengal scores after the use of serum drops. For the two patients who used serum eyedrops post$P K$, there was a stable and intact epithelium at 1 week. Cessation of serum drops during the postoperative period led to deterioration in the subjective and objective scores in both patients. One developed a PED that responded to reinstitution of serum drops. The morphology and ATP levels of cultured epithelial cells exposed to serum were better maintained than those exposed to hypromellose.

Conclusion-Autologous serum drops are useful for PED and KCS. This effect may be related to a number of active factors in serum including growth factors, fibronectin, vitamin $A$, and anti-proteases. In vitro toxicity testing demonstrated that serum drops have reduced toxicity compared with unpreserved hypromellose. Currently regulatory restrictions in the UK have prevented the establishment of a prospective randomised controlled trial examining the efficacy of autologous serum drops for the management of this group of ocular surface disorders.

(Br f Ophthalmol 2001;85:1188-1197)

Serum is the fluid component of blood devoid of its cellular components and clotting factors. Various components of serum, such as albumin and immunoglobulin, are used as treatment for medical conditions. In ophthalmology, there have been reports of the use of autologous serum for diseases of the external eye particularly keratoconjunctivitis sicca (KCS) and persistent epithelial defects (PED)..$^{1-5}$

Tears perform a vital role in maintaining the health of the corneal epithelium. They provide antibacterial factors, prevent desiccation of the cornea, and contain substances like epidermal growth factor (EGF), fibronectin, basic fibroblast growth factor (bFGF), and factors that are thought to maintain epithelial health. ${ }^{6}$ In keratoconjunctivitis sicca the corneal epithelium develops punctate staining, filamentary keratitis, and ulceration due to partial or total tear deficiency. Patients with severe keratoconjunctivitis sicca benefit from intensive topical lubricants, punctal occlusion, and occlusive glasses. However, despite maximal therapy many patients continue to have symptoms and signs of keratoconjunctivitis.

Serum drops have been found to be beneficial for extremely dry eyes. ${ }^{124}$ Fox et al found that 15 out of 15 dry eye patients had improved subjective and objective scores after 
Table 1 Subjective scores for KCS patients

\begin{tabular}{ll}
\hline Grade & Description \\
\hline 0 & $\begin{array}{l}\text { No symptoms } \\
\text { Symptoms were mild, and they did not make me uncomfortable }\end{array}$ \\
2 & $\begin{array}{l}\text { Symptoms were moderate, they did make me uncomfortable, but they did not } \\
\text { interfere with my activities }\end{array}$ \\
3 & $\begin{array}{l}\text { Symptoms were severe, they did make me uncomfortable, and they did not } \\
\text { interfere with my activities }\end{array}$ \\
4 & $\begin{array}{l}\text { Symptoms were very severe, they did make me uncomfortable, and they did } \\
\text { interfere with my activities }\end{array}$ \\
\hline
\end{tabular}

the use of serum drops. ${ }^{1}$ Serum may be helpful because of the presence of substances that enhance epithelial growth and health. These substances, including growth factors outlined above, are normally found in tears and are much decreased in KCS.

Epithelial defects can be caused by a variety of insults to the cornea. Conditions that may lead to non-healing epithelial defects include KCS, exposure keratopathy, neurotrophic cornea, stem cell failure, and post-infectious ulcers. There is evidence suggesting that growth factors and proteins found in the serum may help in the healing of epithelial defects. ${ }^{7-20}$ Tsubota et al found that in 16 eyes with PED treated with autologous serum drops, $62.6 \%$ were healed within 1 month when their mean duration of PED before serum drops was 7.2 months. ${ }^{3}$

At Moorfields Eye Hospital a pilot study was performed to examine the efficacy of autologous serum drops in patients with KCS and PED. A laboratory study was carried out concurrently to evaluate the toxicity of serum drops on human corneal epithelial cell cultures.

\section{Materials and methods}

CLINICAL STUDIES

The clinical features of a prospective cohort of patients who were prescribed serum drops are presented. From July 1998 to June 1999, 29 eyes of 24 patients from one of the author's (JKGD) external disease and corneal clinics were started on autologous serum drops.

Patients were started on serum drops if they were older than 16 years of age and satisfied one of the following criteria:

(1) Dry eye patients with epitheliopathy: (a) symptoms of dry eyes, (b) break up time $($ BUT) $<5$ seconds and Schirmer's test without anaesthesia $<5 \mathrm{~mm}$ at 5 minutes, (c) presence of rose bengal and fluorescein staining of the ocular surface.

(2) Patients with epithelial defects of at least 1 week's duration where conventional therapy had failed. Conventional therapy included antibiotic ointment four times a day, eyelid closure procedures such as botulinum induced ptosis and/or tarsorrhaphy, and therapeutic contact lens wear.

(3) Patients who had just undergone keratoplasty and who had previously demonstrated failure to epithelialise a graft due to existing ocular surface disease (for example, Sjögren's, Stevens-Johnson syndrome, graft versus host disease, ocular cicatricial pemphigoid, and stem cell deficiency).
Patients were not started on serum eye drops if the epithelial defect was classified as a progressive corneal melt caused by an immunological process such as rheumatoid melt or Mooren's ulceration. Patients with active microbial infection, acute herpes simplex or herpes zoster keratitis, drug toxicity, vitamin A deficiency, or recurrent corneal erosion syndrome were also excluded. Patients in whom venesection was not possible (for example, poor venous access), pregnant or lactating females, and those without personal freezing facilities were also excluded.

Patients were examined before treatment and then at 1 and 2 weeks after initiation of treatment. Following that, patients were seen every 2 weeks until serum drops were stopped. Patients were asked to grade their dry eye symptoms from 0 to 4 at each assessment. Table 1 gives the description of each score. Other treatments used in the past and concurrently for PED or KCS were recorded. A history of systemic disease was recorded together with systemic medications used. A full ocular history was also obtained.

Clinical examination included Schirmer's test without anaesthesia, conjunctival rose bengal staining, and corneal fluorescein staining. Scoring of the rose bengal (0-18) and fluorescein (0-15) staining was based on a scoring system suggested by the National Eye Institute/Industry workshop on clinical trials in dry eyes. ${ }^{21}$ Epithelial defects were measured in two dimensions, the longest and its perpendicular dimension.

Serum drops were produced either as a $100 \%$ or a $50 \%$ formulation. The intention was to start all patients on a solution of $50 \%$ serum and $50 \%$ unpreserved chloramphenicol eye drops $(0.5 \%$ chloramphenicol with boric acid $1.5 \%$, borax $0.3 \%$, and purified water). However unpreserved chloramphenicol was not available for 1 month and $100 \%$ serum was used for patients enrolled during that period. In addition, one patient was found to be allergic to chloramphenicol and was changed to $100 \%$ serum. Chloramphenicol was chosen because it is relatively non-toxic and has bacteriostatic properties that would help prevent colonisation of the dropper bottle. ${ }^{22} 23$ Sixteen patients were treated with $50 \%$ serum and six with $100 \%$ (see Tables 2 and 3).

Autologous serum drops were produced in the following manner.

(1) Venesection was performed at the cubital fossa under aseptic conditions.

(2) $25 \mathrm{ml}$ of blood was collected into a sterile container ( $50 \mathrm{ml}$ of blood if $100 \%$ serum was to be produced).

(3) Blood was left standing for 2 hours at room temperature to allow clotting to take place.

(4) Blood was centrifuged at $4000 \mathrm{rpm}$ for 10 minutes.

(5) In a laminar flow cabinet, $3 \mathrm{ml}$ aliquots of serum were removed with disposable pipettes and then deposited into sterile dropper bottles preloaded with $3 \mathrm{ml}$ of chloramphenicol. (For those using $100 \%$ serum, $6 \mathrm{ml}$ aliquots of serum were deposited into empty sterile bottles.) 


\begin{tabular}{|c|c|c|c|c|c|c|c|c|c|c|c|c|c|c|}
\hline Patient & Eye & Age & $\operatorname{Sex}$ & Primary diagnosis & $\begin{array}{l}\text { Percentage } \\
\text { of serum }\end{array}$ & $\begin{array}{l}\text { Other Rx } \\
\text { tried in } \\
\text { past* }\end{array}$ & $\begin{array}{l}\text { Other } R x \\
\text { effective at } \\
\text { same time* }\end{array}$ & $\begin{array}{l}\text { Duration } \\
\text { of PED } \\
\text { (weeks) }\end{array}$ & $\begin{array}{l}\text { Size of } \\
P E D \\
(\mathrm{~mm})\end{array}$ & $\begin{array}{l}\text { Schirmer's } \\
<5 \mathrm{~mm}\end{array}$ & Outcome & $\begin{array}{l}\text { Time of } \\
\text { healing for } \\
\text { successes } \\
\text { (weeks) }\end{array}$ & $\begin{array}{l}\text { Time of } \\
\text { cessation } \\
\text { for failures } \\
\text { (weeks) }\end{array}$ & $\begin{array}{l}\text { Reason for failure and } \\
\text { other relevant } \\
\text { diagnoses }\end{array}$ \\
\hline 1 & $\mathrm{R}$ & 41 & M & $\begin{array}{l}\text { Diabetic neurotrophic } \\
\text { keratitis }\end{array}$ & 100 & SR, P & SC, P & 4 & $1 \times 1$ & No & $S$ & 1 & & \\
\hline 1 & $\mathrm{~L}$ & & & $\begin{array}{l}\text { Diabetic neurotrophic } \\
\text { keratitis }\end{array}$ & 100 & SR, P & SC, $\mathrm{P}$ & 4 & $1 \times 1$ & Yes & $\mathrm{F}$ & & 2 & $\begin{array}{l}\text { Enlarging ulcers at } 2 \\
\text { weeks }\end{array}$ \\
\hline 2 & $\mathrm{R}$ & 75 & $\mathrm{~F}$ & Neurotrophic HSV & 100 & B & SR & 8 & $1 \times 2.5$ & No & $\mathrm{S}$ & 4 & & \\
\hline 3 & $\mathrm{~L}$ & 66 & $\mathrm{~F}$ & Post-HSK & 100 & SR, P & SR, P & 4 & $4 \times 4.5$ & No & $\mathrm{F}$ & & 8 & Slow progress \\
\hline 4 & $\mathrm{~L}$ & 70 & $\mathrm{~F}$ & Post-infectious & 50 & SK, B & & 24 & $9 \times 9$ & No & $\mathrm{F}$ & & 10 & Slow progress \\
\hline 5 & $\mathrm{R}$ & 84 & $\mathrm{~F}$ & OCP & 100 & & $\mathrm{P}$ & 4 & $1.5 \times 1.0$ & Yes & $\mathrm{s}$ & 3 days & & \\
\hline 5 & $\mathrm{~L}$ & & & OCP & 100 & & P, SR & 4 & $7.0 \times 5.5$ & Yes & $\mathrm{F}$ & & 3 & $\begin{array}{l}\text { Microbial keratitis } \\
\text { (coag-ve } \\
\text { staphylococcus) }\end{array}$ \\
\hline 6 & $\mathrm{R}$ & 75 & $\mathrm{~F}$ & $\mathrm{HZO}$ & 50 & $\mathrm{~B} \times 2$ & & 10 & $1.4 \times 2.4$ & No & $\mathrm{S}$ & 4 & & \\
\hline 7 & $\mathrm{~L}$ & 75 & M & RA & 50 & $\begin{array}{l}\text { AMT, P, } \\
\text { SR }\end{array}$ & $\mathrm{P}$ & 12 & $2 \times 1$ & Yes & $\mathrm{S} \ddagger$ & 8 & & $\begin{array}{l}\text { Stitch abscesst } \\
\text { (microbe unknown) }\end{array}$ \\
\hline 8 & $\mathrm{R}$ & 17 & $\mathrm{~F}$ & $\begin{array}{l}\text { Vernal, post-infectious } \\
\text { ulcer in graft }\end{array}$ & 50 & SK & & 6 & $0.25 \times 0.5$ & No & S & 1 & & \\
\hline 9 & $\mathrm{~L}$ & 57 & M & $\begin{array}{l}\text { Neurotrophic HSV } \\
\text { and post-PK for } \\
\text { perforation }\end{array}$ & 50 & LT & LT & 1 & $2.5 \times 3.4$ & Yes & $\mathrm{F}$ & & 2 & Slow progress $\$$ \\
\hline 10 & $\mathrm{R}$ & 51 & M & OCP & 50 & AMT, P, SR & $\mathrm{P}$ & 2 & $2 \times 8$ & Yes & $\mathrm{s}$ & 6 & & \\
\hline 11 & $\mathrm{R}$ & 85 & M & OCP & 50 & SR, P & $\mathrm{P}$ & 6 & $6 \times 3.2$ & Yes & $\mathrm{F}$ & & 2 & Increasing discomfort \\
\hline 12 & $\mathrm{~L}$ & 81 & $\mathrm{~F}$ & Post-infectious, KCS & 50 & $\mathrm{P}$ & $P$ & 6 & $3 \times 4.7$ & Yes & S & 4 & & $\begin{array}{l}\text { Candida infectious } \\
\text { crystalline } \\
\text { keratopathy }\end{array}$ \\
\hline 13 & $\mathrm{R}$ & 86 & $\mathrm{M}$ & Post-infectious, OCP & 50 & $\mathrm{P}, \mathrm{SR}$ & $\mathrm{P}$ & 1 & $7 \times 8$ & Yes & $\mathrm{s}$ & 4 & & \\
\hline
\end{tabular}

$\mathrm{B}=$ botulinum induced ptosis, $\mathrm{P}=$ punctal occlusion, $\mathrm{AMT}=$ amniotic membrane transplant, $\mathrm{SR}=$ silicone rubber contact lens, $\mathrm{SC}=$ scleral contact lens, $\mathrm{S}=$ success, $\mathrm{F}=$ failure.

*All patients were using lubricating ointment unless a therapeutic contact lens was used.

$\dagger$ Diagnosis made at the same time as when epithelium was found to be healed.

$\ddagger$ Recurrent PED after three attempts at stopping serum. Each time the PED responded to recommencement of serum.

§There was time limitation to treatment because patient was from overseas and lack of improvement at 2 weeks led to decision to perform a central tarsorrhaphy and abandon serum drops.

Four bottles of autologous serum were dispensed to each patient in containers with coolant bags keeping the serum cold. Patients were instructed to use the drops eight times a day during waking hours in the affected eye. They were asked to keep the current bottle in the home refrigerator at approximately $5^{\circ} \mathrm{C}$ and to store the extra bottles at $-4^{\circ} \mathrm{C}$ in a freezer. Each bottle was discontinued after 1 week of use. Bottles were cultured only where microbial keratitis was identified on clinical criteria.

In all patients, autologous serum drops were started with little change to the current treatment regime. However, lubrication with drops such as hypromellose (hydroxypropylmethylcellulose $0.3 \%$ ) was decreased so that the frequency of serum and lubricant application was equal to that of lubrication before serum was started.

For the PED patients, failure was defined and serum drops were stopped if (1) surgical intervention was necessary, (2) progress was deemed to be too slow after a trial of 1 month, or (3) the PED was enlarging. Success was defined and serum drops were weaned if closure of the epithelial defect occurred.

Outcome measures for the KCS group were the subjective scores from the questionnaires and the objective scores from fluorescein and rose bengal staining. Serum drops were stopped if patients experienced worsening of symptoms, or if there was no subjective or objective improvement after 1 month. Weaning of serum, for those patients who had benefited from its use, occurred at 2 months. They were asked to taper it to four times a day until the current bottle was finished.
In the two patients using serum after penetrating keratoplasty, drops were stopped at 1 month. Success was defined as the presence of a stable intact epithelium over the donor cornea at 1 month postoperatively. Failure was the absence of a stable intact epithelium at that time.

\section{IN VITRO TOXICITY STUDIES}

In vitro assays were performed to determine the relative toxicity of a range of tear substitutes on corneal epithelial cells without the complex influence of corneal pathologies. The hypothesis was that different tear substitutes would have different effects upon corneal epithelial cell survival. Primary corneal epithelial cells were obtained from human corneal donor tissue stored in Optisol at $4^{\circ} \mathrm{C}$ following trephination of the central corneal button for a corneal graft. Corneal rims were used up to 5 days post mortem. Following incubation at $37^{\circ} \mathrm{C}$ for 2 hours with $1.2 \mathrm{IU} / \mathrm{ml}$ Dispase II (neutral protease; Boehringer Mannheim, Germany) the epithelium was stripped off with gentle scraping from the limbus to the centre into phosphate buffered saline (PBS). This was centrifuged at $100 \mathrm{~g}$ for 5 minutes and the cells grown using routine cell culture methods and keratinocyte serum free medium (K-SFM, Gibco Life Technologies, Paisley, UK) ${ }^{24}$ Immunohistochemistry with mouse monoclonal antibodies (ICN-flow, UK) using the alkaline phosphatase method ${ }^{25}$ stained the cells strongly positive for human cytokeratin-3 thus confirming that the cells were of corneal epithelial origin.

All experiments were performed on cells at passage $2-4 ; 36$ hours after seeding them at a 

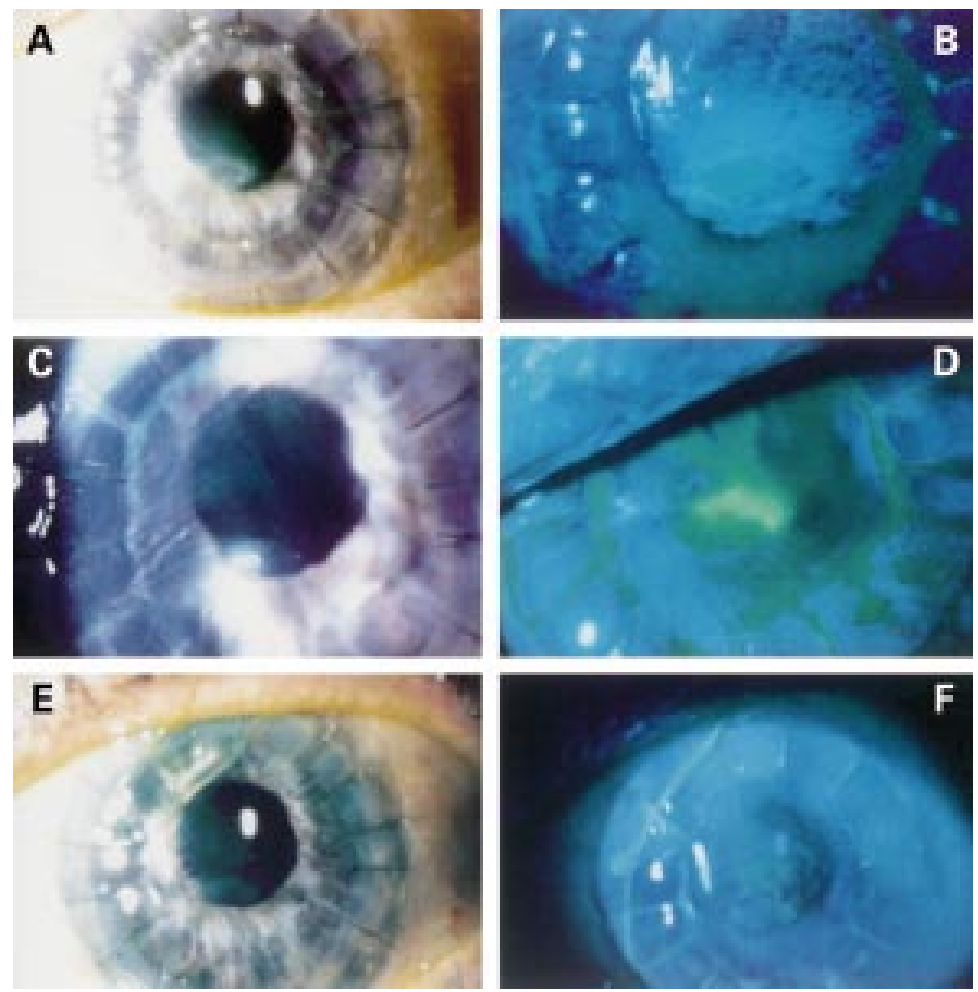

Figure 1 This is a 74 year old man with KCS secondary to rheumatoid arthritis. History includes left infective corneal melt 3 years ago requiring a tectonic PK. This was followed by recurrent epithelial breakdown unresponsive to intensive lubrication and SRCL wear. The cornea perforated again requiring a repeat PK 3 months before the start of serum drops. The $P E D$ recurred and amniotic membrane transplantation was tried but failed to heal it.

Serum drops were started subsequently. $(A, B)$ Show a PED with and without fluorescein and cobalt blue illumination before the start of serum. (C) Shows that healing occurred in 2 months (epithelial bullae at site of PED). Serum was stopped after 2 months, and the PED recurred (D). It failed to respond to any therapy apart from the reinstitution of serum. (E) and $(F)$ show healed defect with and without cobalt blue illumination. The PED recurred with further attempts at weaning and healed with reinstitution of serum. At the last review serum was weaned for the fourth time.

density of 15000 into 96 well culture plates, wells were washed twice with buffered saline and exposed to $200 \mu \mathrm{l}$ undiluted unpreserved hydroxypropylmethylcellulose $0.3 \%$ as produced by the Pharmacy Department of Moorfields Eye Hospital or $50 \%$ and $100 \%$ serum drops (as used in the clinical study) for 2 hours. For controls wells were incubated with $1 \%$ benzalkonium chloride (positive control) or culture medium (negative control). Following this the total ATP of the cultured cells was quantified. Also, ATP was quantified after exposure of the cells to $100 \%$ serum of six healthy normal volunteers versus $100 \%$ serum of eight patients with at least one systemic immunosuppressive medication for ocular cicatricial pemphigoid (for example, cyclophosphamide or azathioprine). In addition toxicity was visualised by means of a viability stain which demonstrates abnormal cell membrane permeability.

In the viability staining the live/dead assay was used (Molecular Probes, Eugene, OR, USA). In this the non-fluorescent Calcein-AM is converted into green fluorescent calcein by intracellular esterase and indicates the presence of active cell metabolism. The second dye, ethidium homodimer, is usually excluded by viable cells. However, it permeates damaged cell membranes and binds to nucleic acids resulting in red fluorescence. Dead or dying cells stain red while viable cells stain green. For this assay the test agents were removed, the cells washed twice with PBS and then incubated with $100 \mu \mathrm{l}$ of $4 \mu \mathrm{M}$ ethidium homodimer with $2 \mu \mathrm{mol}$ Calcein-AM for $30 \mathrm{~min}$ utes at room temperature. The cells were then immediately viewed at $485 \mathrm{~nm}$ excitation and $530 \mathrm{~nm}$ (Calcein)/645 nm (ethidium) emission wave length.

In the ATP assay all intracellular ATP was extracted and preserved from each cell culture by adding $50 \mu 1$ of a somatic cell extraction reagent (DCS, Innovative Diagnostik Systeme, Hamburg/Germany) to each well. Following 20 minutes of incubation at room temperature, $50 \mu \mathrm{l}$ of luciferin-luciferase was added to each well and the resulting luminescence read immediately (Dynatech, ML 1000). The mean ATP count of the wells was calculated. All experiments were performed in triplicate and repeated twice

The percentage of cell growth inhibition (CGI) for each drug and test situation, compared with the cell culture incubated with culture medium, was calculated as follows:

$$
1.0-(\text { Test }-\mathrm{MI} / \mathrm{MO}-\mathrm{MI}) \times 100=\% \mathrm{CGI}
$$

where $\mathrm{MO}=$ mean counts for no inhibition control cultures (that is, after incubation with culture medium), $\mathrm{MI}=$ mean counts for maximum inhibition control cultures (that is, after incubation with benzalkonium chloride $1 \%$ ) and Test $=$ mean counts for triplicate test situation (that is, serum drops or hypromellose). Wilcoxon sign rank test for non-parametric data was used to determine the significance of differences.

\section{Results}

CLINICAL STUDIES

Autologous serum was used in 15 eyes of 13 patients with PED and 11 eyes of nine patients with KCS. In two patients, serum drops were started after penetrating keratoplasty (PK). The PKs were performed for perforations secondary to PEDs. The female:male ratios were 8:7, 9:1, 1:1 in the PED, KCS, and the post-PK group, respectively. The means and ranges of age were 66 (17-86), 56 (41-79), 41 (40-42) for the PED, KCS, and the post-PK group respectively.

\section{PERSISTENT EPITHELIAL DEFECT GROUP}

In the PED group, before initiation of the serum drops, three eyes had botulinum induced ptosis, seven had tried therapeutic contact lens (TCL) wear, two had received amniotic membrane transplantation, and one had a lateral tarsorrhaphy to encourage epithelial healing. In addition, two had superficial keratectomies to remove necrotic tissue and improve the stromal bed and thus facilitate epithelial growth. Unless contraindicated (for example, with therapeutic contact lens use) all patients were using antibiotic ointment for lubrication. Four eyes did not have a lid closing procedure or a TCL as therapy for PED. This was because, for the patients involved, the contralateral eyes had poor best corrected vision 
Table 3 Summary of the KCS patients

\begin{tabular}{|c|c|c|c|c|c|c|c|c|c|c|c|c|c|c|c|c|c|}
\hline Patient & Eye & Age & Sex & $\begin{array}{l}\text { Primary } \\
\text { condition }\end{array}$ & $\begin{array}{l}\text { Serum } \\
\%\end{array}$ & Subj & $R B^{l}$ & Fluo $^{2}$ & $\begin{array}{l}\text { Subj } 1 \\
\text { month }\end{array}$ & $\begin{array}{l}R B^{1} 1 \\
\text { month }\end{array}$ & $\begin{array}{l}\text { Fluo }^{2} 1 \\
\text { month }\end{array}$ & $\begin{array}{l}\text { Subj } 2 \\
\text { months }\end{array}$ & $\begin{array}{l}R B^{I} 2 \\
\text { months }\end{array}$ & $\begin{array}{l}\text { Duration } \\
\text { of use }\end{array}$ & Side effects & $\begin{array}{l}\text { Other Rx at } \\
\text { same time }\end{array}$ & $\begin{array}{l}\text { Other Rx } \\
\text { previously }^{a}\end{array}$ \\
\hline 1 & $\mathrm{R}$ & 52 & $\mathrm{~F}$ & $\begin{array}{l}\text { Linear } \\
\text { IgA }\end{array}$ & 50 & 4 & 8 & 8 & $\star$ & $\star$ & $\star$ & & & 3 weeks & $\begin{array}{l}\text { Itch, pain and } \\
\text { discharge }\end{array}$ & & $\mathrm{V}, \mathrm{H}$ \\
\hline 2 & $\mathrm{R}$ & 79 & $\mathrm{~F}$ & OCP & 100 & 4 & 14 & 13 & 1 & 3 & 5 & 1 & $2^{\mathrm{b}}$ & 7 months & Allergic to CAP & & $\mathrm{H}$ \\
\hline 3 & $\mathrm{R}$ & 52 & $\mathrm{~F}$ & OCP & 100 & 4 & 4 & 6 & 2 & 3 & 5 & 2 & 4 & 2 month & & & $\mathrm{H}$ \\
\hline 3 & $\mathrm{~L}$ & & & $\mathrm{OCP}$ & 100 & 4 & 12 & 11 & 2 & 7 & 10 & 2 & 4 & 2 month & & & $\mathrm{H}$ \\
\hline 4 & $\mathrm{R}$ & 55 & $\mathrm{~F}$ & Sjøgren & 50 & 3 & 9 & 8 & * & * & $\star$ & & & 1 day & $\begin{array}{l}\text { Small peripheral } \\
\text { sterile infiltrate } \\
\text { with overlying } \\
\text { defect }\end{array}$ & & \\
\hline 5 & $\mathrm{R}$ & 73 & $\mathrm{~F}$ & Sjøgren & 50 & 4 & 16 & 12 & * & * & * & & & 1 week & $\begin{array}{l}\text { Swelling and } \\
\text { redness }\end{array}$ & & V, A \\
\hline 6 & $\mathrm{R}$ & 69 & $\mathrm{~F}$ & Sjøgren & 50 & 4 & 12 & 7 & 3 & 12 & 5 & 3 & 8 & 2 months & & & \\
\hline 7 & $\mathrm{R}$ & 55 & $\mathrm{~F}$ & Sjøgren & 50 & 4 & 8 & 9 & 1 & 3 & 6 & & & 1 month & & & $\mathrm{H}, \mathrm{SC}, \mathrm{SR}$ \\
\hline 8 & $\mathrm{R}$ & 45 & $\mathrm{~F}$ & SJS & 50 & 4 & 10 & 14 & 2 & 7 & 6 & 2 & $6^{\mathrm{b}}$ & 3 months & & SR & \\
\hline 9 & $\mathrm{R}$ & 41 & M & SJS & 50 & 2 & 6 & 5 & 2 & 6 & 5 & & & 2 weeks & & & A \\
\hline 9 & $\mathrm{~L}$ & & & SJS & 50 & 2 & 9 & 4 & 2 & 9 & 11 & & & 2 weeks & & & A \\
\hline
\end{tabular}

$\mathrm{a}=$ All patients had puncti occluded and were on 10 minute to 2 hourly hypromellose or saline (without preservative) drops and twice to four times daily ointment. $\mathrm{b}=$ continued drops for more than 2 months. 1 = National Eye Institute Rose Bengal scoring system (0-18). 2 = National Eye Institute Fluorescein scoring system $(0-15) . \mathrm{RB}=$ rose bengal score, Fluo = fluorescein score, $\mathrm{Subj}=$ subjective score, $\mathrm{Rx}=$ treatment, $\mathrm{V}=$ viscotears, $\mathrm{A}=$ acetylcysteine, $\mathrm{H}=$ hyaluronic acid $(\mathrm{Healon})$, $\mathrm{SC}=$ scleral contact lens, $\mathrm{SR}=$ silicone rubber contact lens. $\mathrm{OCP}=$ ocular cicatricial pemphigoid, $\mathrm{SJS}=\mathrm{Stevens-Johnson}$ syndrome, $\mathrm{CAP}=$ chloramphenicol. ${ }^{\star}$ Patients felt worse and stopped serum drops. They were not available for review at time of discomfort while they were still on serum. At time of review a week or more later the findings were the same as the pretreatment parameters.

and contact lens fitting on the ipsilateral eye was not possible due to short fornices in OCP or lens intolerance. In five patients a TCL was used at the same time as serum drops. Nine of the 15 eyes had a Schirmer's test of less than $5 \mathrm{~mm}$ and six of the nine were eyes of patients with rheumatoid arthritis or OCP. All of the nine eyes had occluded ipsilateral upper and lower puncta.

A summary of the patients is presented in Table 2. Figure 1 shows a patient whose response to serum supports the beneficial action of serum on epithelial defects. Of the 15 eyes with PED, nine healed at a mean of 29 days (range 3-60 days, median 28 days), and six failed. The mean duration of PED before the use of serum drops was 48.2 days. In six eyes $100 \%$ serum drops were used and there were three successes and three failures. For nine eyes, $50 \%$ serum was used and there were six successes and three failures.

One patient with diabetic neurotrophic keratopathy had an enlarged defect after 2 weeks' use. Three patients developed an infection during the course of treatment. One had a stitch abscess away from the epithelial defect. An organism was not identified from culture of scrapings and sutures. Another patient developed candida infectious crystalline keratopathy although the persistent epithelial defect had healed. In the third patient a keratitis caused by coagulase negative staphylococcus developed around the site of the epithelial defect. As the epithelium had healed in the first two patients they were classified as successes. A scanty growth of the same organism that caused the keratitis was found on culturing the residual serum of the second and third patients. The serum was macroscopically clear and not grossly contaminated in both cases.

Five out of the nine eyes that were successes had epithelial breakdown on cessation of the serum. In two out of the five, reepithelialisation occurred with conventional therapy (without serum). Healing occurred only with reinitiation of serum in another. In the other two eyes, epithelial breakdown coincided with the starting of intensive topical medications that took place at the same time as cessation of serum. One patient started amphotericin $(0.15 \%)$ hourly day and night for candida keratitis. The other started ofloxacin drops four times a day and dexamethasone 2 hourly by day for treatment of anterior segment inflammation secondary to infective posterior scleritis. The patient with candida keratitis required a therapeutic graft and then a conjunctival flap to stabilise the ocular surface. The other patient had a PED at last review, 2 weeks after the start of the antibiotics. Serum was not recommenced in these two patients.

\section{KERATOCONJUNCTIVITIS SICCA GROUP}

Patients with KCS had symptoms of dry eyes for more than 1 year. All had been treated with intensive topical lubricants consisting of frequent unpreserved drops and ointment. In addition their puncta were all occluded either by the disease process or surgically. One had tried silicone rubber contact lenses for comfort and five had tried $0.1 \%$ sodium hyaluronate drops with limited success.

Of the 11 eyes with KCS, six had improved subjective scores, five had improved rose bengal scores, and six had improved fluorescein scores after the use of serum drops. Patients with decreased discomfort noted an improvement within 48 hours after serum was started. Table 3 is a summary of the patients and their scores. Figure 2 demonstrates the beneficial effect of serum on one patient.

In the KCS group, assuming that those who stopped the drops because of discomfort had increased subjective scores, five patients had worse symptomatic and objective scores while on serum drops. One patient with rheumatoid arthritis developed a marginal infiltrate and an overlying epithelial defect after 1 day of use. Another with Stevens-Johnson syndrome had increased ocular surface fluorescein staining. Two patients complained of increased discomfort and stopped the serum. However, when reviewed in the clinic 1 week after cessation of serum, they essentially showed no 

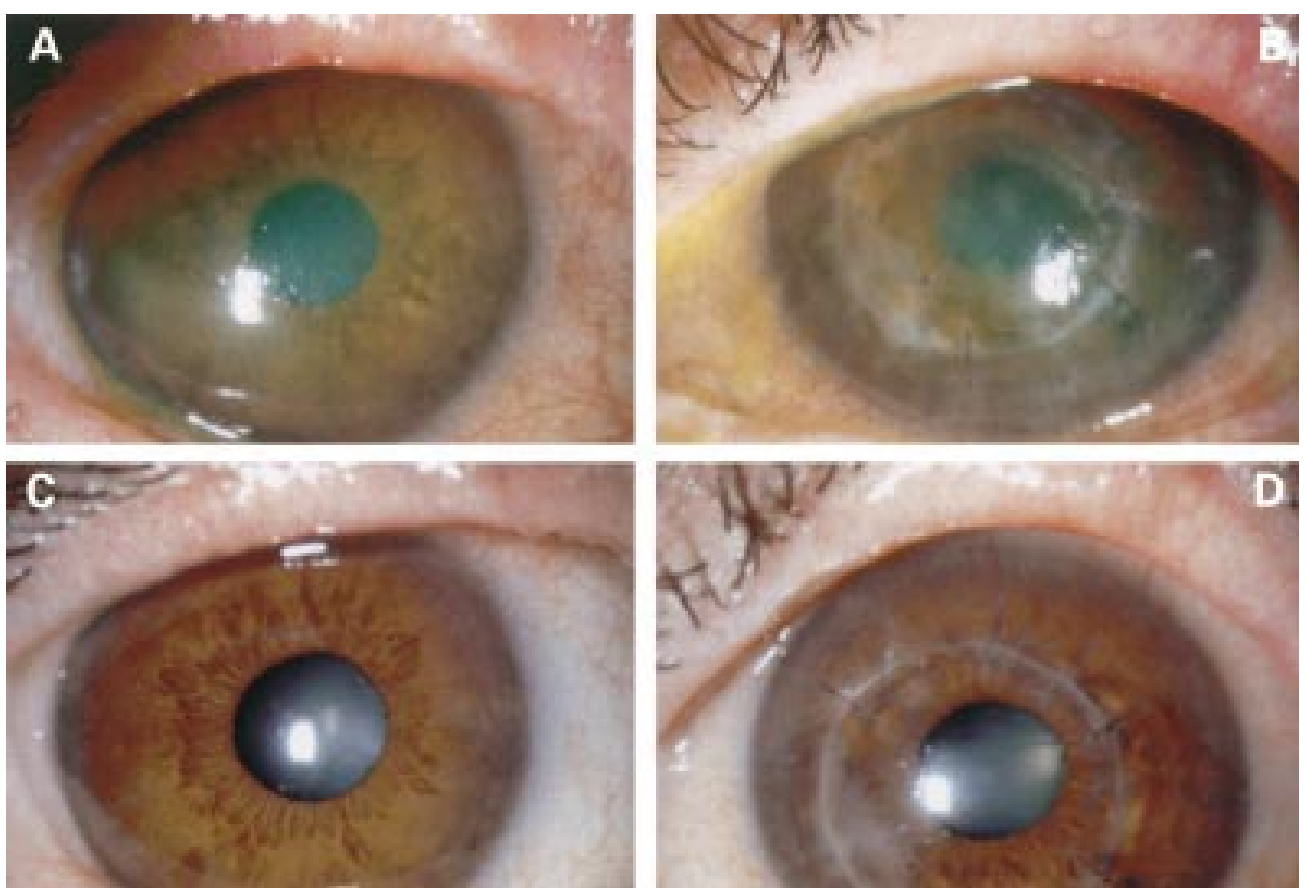

Figure 2 A 52 year old female with OCP, bilateral KCS, and left PK. Bilateral epitheliopathy was secondary to KCS. $(A)$ and $(B)$ show right and left eyes respectively. Serum drops were started and $(C)$ and $(D)$ were taken at 2 week review. Despite the absence of fluorescein in (C) and (D), there are obviously fewer surface irregularities and episcleral injection in the second set of photographs. Both objective and subjective scores had improved.

change in their clinical picture. One patient had an allergic reaction to chloramphenicol and was successfully treated with $100 \%$ serum.

In eight of the KCS eyes $50 \%$ serum drops were used and three had improved subjective and/or objective scores. The remaining three KCS eyes had $100 \%$ drops and they all had improved subjective and/or objective scores. The patient who was allergic to chloramphenicol was changed from $100 \%$ serum to $50 \%$ serum diluted with normal saline and she was able to detect the difference and insisted on being restarted on $100 \%$ serum.

Patients who were benefiting from serum were weaned off serum at 2 months to reduce the demands on clinical resources. In two patients the clinical circumstances required serum to be continued for more than 2 months. All other patients reported decreased comfort after cessation and were offered recommencement of serum if symptoms and signs deteriorated significantly.

POST-PENETRATING KERATOPLASTY GROUP

The two patients who used serum eye drops post-PK had stable and intact epithelium at 1 week. Cessation of serum drops at 1 month postoperatively led to deterioration in the subjective and objective scores in both patients. One patient with graft versus host disease had two previous graft failures from epithelial instability and secondary perforations. Serum drops were started after the third PK. At 1 month postoperatively serum drops were stopped. Although she was on hourly unpreserved hypromellose $(0.3 \%)$ and Lacrilube ointment four times a day, she developed an epithelial defect that was unchanged at 2 weeks. It healed within 21 days after reinstitution of serum drops. The other patient had Stevens-Johnson syndrome and perforated secondary to a PED, which required a tectonic PK. Serum was commenced immediately postoperatively and was weaned at 1 month. Fluorescein score at 1 month postoperatively, while he was on serum was less than 4 out of a possible 15. At review 1 month after cessation of serum, the score was more than 10. Although there was more corneal epithelial fluorescein staining after cessation of serum, the epithelium was maintained with intensive lubrication.

IN VITRO TOXICITY STUDIES

The live/dead fluorescent staining following incubation with culture medium (negative control) revealed that the cultured primary human corneal epithelial cells all remained viable. Incubation with $50 \%$ serum drops (Fig 3A) preserved the cell membrane integrity much better than with unpreserved hydroxypropylmethylcellulose $0.3 \%$ (Fig 3B).

The mean reduction in cellular viability as measured with the ATP assay for the various test substances is given in Table 4. Fifty per cent serum reduced cell viability significantly less than unpreserved hypromellose ( $\mathrm{p}=$ 0.04). The following trends were present: $100 \%$ serum seemed to maintain cellular ATP levels better than $50 \%$ serum $(p=0.11)$ and serum of patients on systemic immunosuppressive therapy seemed to be less toxic than serum of healthy normal individuals $(\mathrm{p}=$ 0.08 ) but neither finding was statistically significant. 

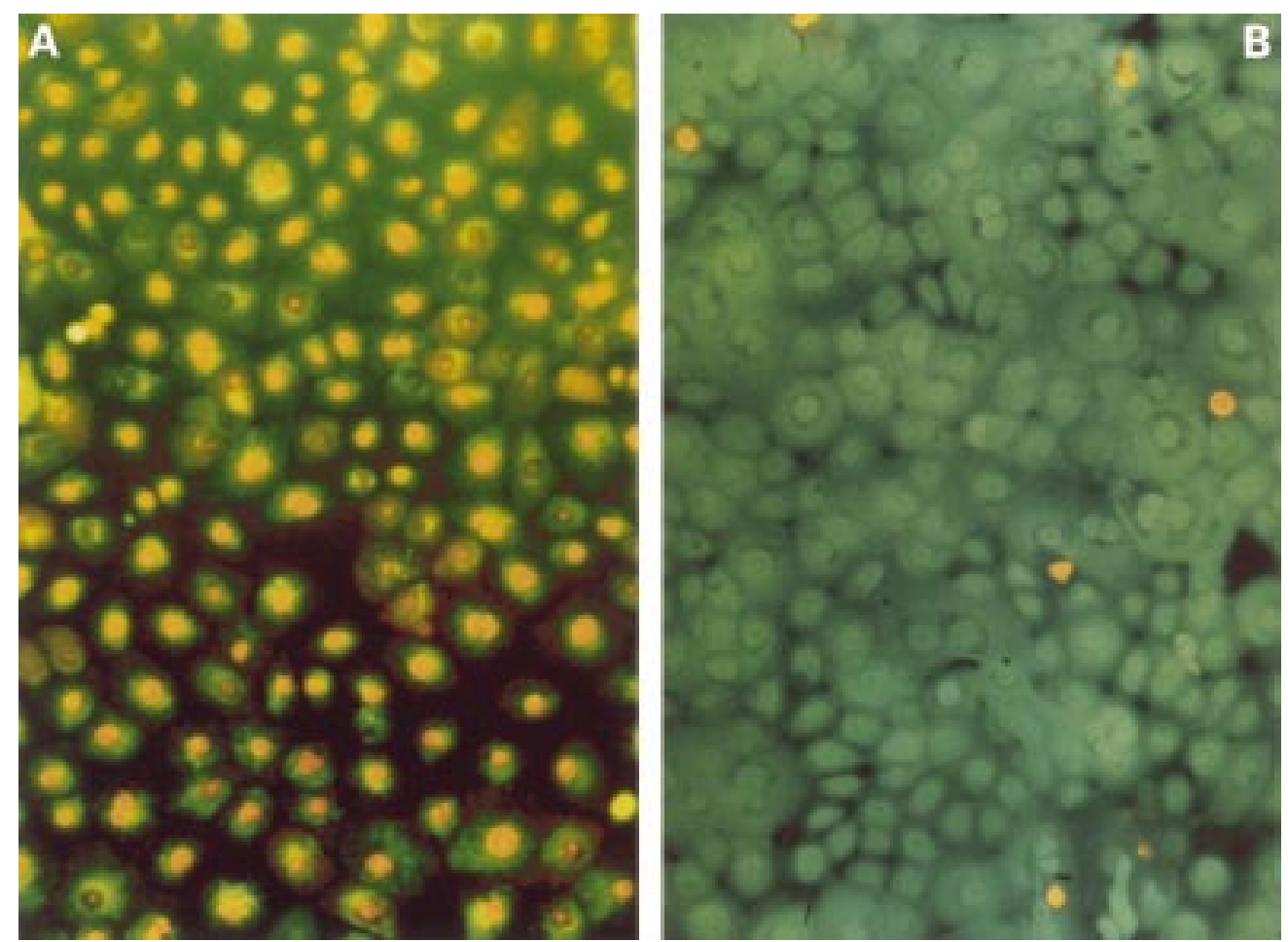

Figure 3 Human corneal epithelial cells after 2 hours' incubation with (A) hypromellose $0.3 \%$ and (B) $50 \%$ serum drops. The green fluorescent calcein demonstrates viable intracellular esterase activity. The red fluorescence results from ethidium-homodimer bound to nucleic acids as a consequence of a pathological increase in cell membrane permeability.

\section{Discussion}

The favourable result associated with the use of autologous serum in patients with dry eyes and persistent epithelial defect has been described by various authors. ${ }^{13-5}$ This pilot study supports those claims. Epithelial defects in nine out of 15 eyes healed during treatment with autologous serum. In all 15 eyes previous treatment with antibiotic ointment four times a day had failed. Eleven out of 15 had failed to heal with an eyelid closing procedure (botulinum induced ptosis, lateral tarsorrhaphy), and/or therapeutic contact lens application. The average duration of PED before the use of serum drops was 48 days. Healing occurred at a mean of 29 days and a median of 28 days in the successful cases. Epithelial defects recurred in five eyes after cessation of the serum. Figure 1 shows a patient's eye whose corneal epithelial healing appear to depend on the use of serum drops.

In two patients, serum was used after tectonic penetrating keratoplasty performed for perforations secondary to PED. Both patients had poor ocular surfaces and aqueous tear deficiency and had a stable epithelium 1 week postoperatively. Both experienced deterioration when serum was stopped.

For the KCS patients, six out of 11 eyes had improved subjective and fluorescein scores and five had improved rose bengal scores. All patients were on maximal conventional therapy for KCS. In five eyes previous topical sodium hyaluronate $(0.1 \%)$ application had not given satisfactory relief. Four out of these five patients stated that serum gave more relief.

Fetal calf serum is extensively used in the laboratory to promote cell growth in culture. Tsubota et al showed that fetal calf serum accelerates the migration of corneal epithelial cells in vitro. ${ }^{3}$ Serum also has been used for treating canine corneal ulcers with success. ${ }^{26}$ The reason why serum is of benefit to the ocular surface is not entirely clear, but epidermal growth factor (EGF) is present in both tears and serum ${ }^{4}$ and has been found to be helpful in healing of traumatic epithelial

Table 4 Results of ATP assay: mean percentage of cell viability reduction (SD) following 2 hours of incubation with test agent. 50\% serum reduced the viability of cultured cells significantly less than unpreserved hypromellose ( $p=0.04) .100 \%$ serum maintained cellular ATP levels better than $50 \%$ serum $(p=0.11)$ and serum of patients on systemic immunosuppressive therapy was less toxic than serum of healthy normal individuals ( $p=0.08)$ although these trends did not reach statistical significance

\begin{tabular}{|c|c|c|c|}
\hline & $\%$ Viability reduction & $\begin{array}{l}p \text { Value (in comparison } \\
\text { with negative control) }\end{array}$ & $p$ Value for other tests \\
\hline Hypromellose $0.3 \%$ unpreserved ( $\mathrm{n}=4$ tests) & $87(14)$ & 0.03 & - \\
\hline $\begin{array}{l}50 \% \text { serum (serum diluted } 1: 1 \mathrm{v} / \mathrm{v} \text { with } 0.5 \% \text { chloramphenicol eye } \\
\text { drops, } \mathrm{n}=5 \text { patients) }\end{array}$ & $58(25)$ & 0.046 & 0.04 ( $v$ Hypromellose $0.3 \%$ ) \\
\hline $100 \%$ serum of normal individual $(n=6)$ & $34(10)$ & 0.03 & $0.11(v 50 \%$ serum $)$ \\
\hline $\begin{array}{l}100 \% \text { serum of patients with dry eyes treated with autologous } \\
\text { serum }(n=4)\end{array}$ & $24(22)$ & 0.72 & \\
\hline $100 \%$ serum of immunosuppressed patients $(n=8)$ & $26(7)$ & 0.17 & 0.08 ( $v$ serum of normal individuals) \\
\hline
\end{tabular}


abrasions. ${ }^{17}{ }^{19}$ EGF may also facilitate epithelialisation because of its anti-apoptotic properties. ${ }^{27}{ }^{28}$ Acidic and basic fibroblast growth factors ( $\mathrm{aFGF}, \mathrm{bFGF}$ ) were found to speed up healing of epithelial defects in rabbits. ${ }^{20}$ Fibronectin, another component of serum, has also been found to have some effect in helping epithelialisation $^{911}{ }^{12}$ but a randomised control trial showed no significant effect compared to placebo except in eyes with large baseline defects $\left(10 \mathrm{~mm}^{2}\right.$ or more). ${ }^{10}$ Vitamin $\mathrm{A}$ is found in much higher concentrations in serum compared to tears and may decrease the progression to squamous metaplasia in $\mathrm{KCS} .{ }^{4}$ Mucin expression by cultured conjunctival epithelial cells is upregulated by human serum $^{4}$ and this may contribute to the beneficial effects of serum in KCS. Serum antiproteases such as $\alpha_{2}$ macroglobulin have been thought to inhibit corneal collagenases and be beneficial in conditions such as alkali burns. ${ }^{29}$ Neural factors such as substance $P$ are important for corneal epithelial migration. ${ }^{18}$ In neurotrophic ulcers, these substances are decreased and may be supplemented by topical serum.

Stability data on serum are limited but Tsubota reported levels of EGF, TGF, and vitamin $\mathrm{A}$ in $20 \%$ serum (diluted with saline) and $100 \%$ serum remained stable at $4^{\circ} \mathrm{C}$ for at least 1 month and at $-20^{\circ} \mathrm{C}$ for at least 3 months. ${ }^{34}$

In dry eyes pharmaceutical products are used to substitute the deficient tear film. In the majority of patients they are sufficient to relieve symptoms and to prevent progressive ocular surface disease. However, in absolute tear deficiency pharmaceutical tear substitutes are often ineffective in controlling the symptoms and signs of the disease. Despite their frequent application epithelial defects may occur, persist, or even progress to corneal perforation, as was the case in the patients of the post-PK group in the current study. Our in vitro observations confirm that pharmaceutical tear substitutes, such as unpreserved hydroxypropylmethylcellulose $0.3 \%$, are inappropriate to maintain intracellular ATP levels and cell membrane integrity of cultured human corneal epithelial cells. Both are well established parameters of cellular viability and/or proliferation for in vitro evaluations of toxicity. ${ }^{3031}$ Certainly the complex physical and molecular interactions of tear film and ocular surface in vivo can not be substituted in vitro. In vivo studies are however much more difficult to standardise. Furthermore, physiological tear substitutes such as serum are usually reserved for the more severe aqueous deficient dry eyes. As the ocular surface epithelia are more susceptible to toxicity in this situation in vitro evaluations may be more appropriate. ${ }^{32-34}$ Furthermore, the assay period was 2 hours and hence not long enough for a depletion of nutrients to be responsible for the relative decrease in viability observed with hypromellose. If the cells had been cultured at a similar density in phosphate buffered saline for his time period toxicity would not have been evident. Owing to the precautions taken in defining the culture model (for example, primary human epithelial cells, cultured under fully defined conditions) we believe that the model used here allows extrapolation to the acute toxicity of pharmaceutical and natural tear substitutes on human corneal epithelium in vivo.

Pharmaceutical tear substitutes provide lubrication but not nutrition. Previous attempts to construct a physiological tear substitute $^{3536}$ focused on the ionic composition. Compared to the complex composition of serum such substitutes are very limited in their replacement of the nutritional component of endogenous tears. Our in vitro experiments show that serum, despite being diluted with chloramphenicol, is able to maintain the viability of human corneal epithelial cells in culture. This suggests that serum may have a therapeutic role in addition to a pharmaceutical role as a tear substitute.

The concentration of serum in drops has varied with different studies. Fox used 30\% serum diluted with normal saline and all of 15 patients had improved subjective and objective scores. ${ }^{1}$ Tsubota suggested using $20 \%$ serum diluted with saline and achieved good results. ${ }^{3}$ In this study we used $50 \%$ serum, and because of concern with microbial contamination of the serum bottles we used chloramphenicol as a diluent. Chloramphenicol was chosen because of its relatively low epithelial toxicity. ${ }^{22} 23$

In one patient $100 \%$ was much preferred compared to $50 \%$ serum diluted with unpreserved normal saline. In the KCS group three out of eight of those using $50 \%$ drops compared to three out of three of those using $100 \%$ drops had improved scores. This, as well as the finding that $100 \%$ serum inhibits cellular growth less than $50 \%$ serum diluted with $0.5 \%$ chloramphenicol, suggests a higher percentage of serum may give a greater effect. However the frequency of venepuncture and the amount of blood needed is doubled with the use of $100 \%$ drops. $55 \%$ of our KCS patients had improved scores. This is less than that found by Fox and Tsubota, ${ }^{14}$ which may relate to differences in the patient population or to the different composition of the dispensed drops.

Three patients with PED developed infectious keratitis while on serum drops. Two of them were using $50 \%$ serum with chloramphenicol and the other was using $100 \%$ serum. All three patients had risk factors that may have contributed to the infection. One patient with rheumatoid arthritis and secondary KCS had a corneal graft with sutures in situ. The next patient had KCS and corneal graft with sutures in situ and had previously had an episode of microbial keratitis related to sutures. The third patient had KCS and a therapeutic contact lens was in use for corneal perforation secondary to persistent epithelial 
defect. This patient had refused a tectonic PK. Contaminated serum bottles may have introduced bacteria to the compromised ocular surface. The potential for microbial growth in serum and the contamination of serum dropper bottles in clinical use has not been evaluated. Meanwhile we are using chloramphenicol with serum unless contraindicated by hypersensitivity. Chloramphenicol was chosen as it is our drug of choice in patients with PED for prophylaxis against microbial keratitis.

No significant complications have been reported with the use of serum drops. There is one case report of immunoglobulin deposition in the cornea of a patient with persistent epithelial defect. ${ }^{31}$ We did not encounter this in our series. However, one patient with rheumatoid arthritis did develop peripheral infiltration and ulceration after 1 day of use. This may be related to the use of serum. Rheumatoid factor and other antigens together with autoantibodies present in serum could theoretically cause immune complex deposition and secondary inflammation.

Of the patients with KCS who responded to serum, the effect was rapid. Most claimed the effect was almost instantaneous and all said the symptoms were improved by 48 hours. For the PED patients who were successes, a positive response was usually seen by 2 weeks, but the average healing time was approximately 1 month.

Serum drops have been shown to have low toxicity in vitro and have demonstrated encouraging results in patients with keratoconjunctivitis sicca and epithelial defects who have failed to respond to currently available treatment. Their use should also be considered in patients requiring penetrating or lamellar keratoplasty in whom problems with epithelial healing are anticipated. As this study was uncontrolled and unmasked, there were inherent problems in interpretation of the results. The true value of autologous serum requires a randomised controlled trial. Regulatory restrictions in the $\mathrm{UK}$, because of the absence of standards regarding the manufacture of biological materials as eye drops, have currently precluded the use of a randomised controlled trial to assess the use of serum drops.

Currently the results of uncontrolled studies on the effect of serum drops are favourable and several issues concerning the manufacturing and storage of the drops need resolution. These include quantification of the antimicrobial properties of serum to determine whether a preservative is needed, the minimum concentration required for an acceptable positive effect, optimum storage times and identification of the factors in serum that lead to the effect on epithelial healing. The goal of future studies is to emulate the effect of serum, for the management of this challenging group of disorders, without the need for biological materials.
This work wassupported in part by funding from the NHS Executive (locally organised research grant 485), special trustees of Moorfields Eye Hospital, and the Deutsche Forschungsgemeinschaft (DFG Ge 895/4-1; the views expressed in this publication are those of the authors and not necessarily those of the funding bodies.

1 Fox RI, Chan R, Michelson J, et al. Beneficial effect of artificial tears made with autologous serum in patients with keratoconjunctivitis sicca. Arthritis Rheum 1984;29:57783.

2 Tseng SCG, Tsubota K. Important concepts for treating ocular surface and tear disorders. Am $\mathcal{f}$ Ophthalmol 1997;124:825-35.

3 Tsubota K, Goto E, Shimmura S, et al. Treatment of persistent epithelial defect by autologous serum application. Ophthalmology 1999;106:1984-9.

4 Tsubota K, Goto E, Fujita H, et al. Treatment of dry eye by autologous serum application in Sjogren's syndrome. $\operatorname{Br} \mathcal{F}$ Ophthalmol 1999;83:390-5.

5 Tsubota K, Satake Y, Ohyama M, et al. Surgical reconstruction of the ocular surface in advanced ocular cicatricial pemphigoid and Stevens-Johnson syndrome. Am f Ophthalmol 1996;122:38-52.

6 Nishida T. Cornea. In: Krachmer, Mannis, Holland, Pally, eds. Cornea. St Louis: Mosby, 1998;1:3-27.

7 Schultz GS, Davis JB, Eiferman RA. Growth factors and corneal epithelium. Cornea 1988;7:96-101.

8 Ubels JL, Edelhauser HF, Austin KH. Healing of experimental corneal wounds treated with topically applied retinoids. Am f Ophthalmol 1983;95:353.

9 Nishida T, Ohasai Y, Awata T, et al. Fibronectin a new therapy for corneal trophic ulcer. Arch Ophthalmol 1983; 101:1046.

10 Gordon JF, Johnson P, Musch DC. Topical fibronectin ophthalmic solution in the treatment of persistent defects of the thalmic solution in the treatment of persistent defects of the

11 Cluskey P, Wakefield D, York L. Topical fibronectin therapy in persistent corneal ulceration. Aust NZ $\mathcal{F}$ Ophthalmol 1987;15:257-62.

12 Phan TM, Foster CS, Boruchoff SA, et al. Topical fibronectin in the treatment of persistent corneal epithelial defects and trophic ulcers. Am f Ophthalmol 1987;104:494501.

13 Eiferman R, Brightwell J, Rowsey J, et al. Acceleration of corneal epithelial resurfacing and keratocyte migration in primate epikeratophakia by biosynthetic human EGF. Invest Ophthalmol Vis Sci 1985;(suppl):26

14 Eiferman R, Schultz GS. Treatment of alkali burns in rabbits with epidermal growth factor. Invest Ophthalmol Vis Sci 1987; (suppl)28:52.

Sci 1987; (suppl)28:52.
15 Singh G, Foster CS. Epidermal growth factors in alkaliburned corneal epithelial wound healing. Am f Ophthalmol burned corneal

16 Reim M, Kehrer T, Lund M. Clinical application of epidermal growth factor in patients with severe eye burns. Ophthalmologica 1988;197:179-84.

17 Scardovi C, De Felice GP, Gazzaniga A. Epidermal growth factor in the topical treatment of traumatic corneal ulcers. Ophthalmologica 1993;206:119-24.

18 Nishida T, Nakamura M, Ofuji K, et al. Synergistic effects of substance $\mathrm{P}$ with insulin-like growth factor-1 on epithelial migration of the cornea. $\mathcal{F}$ Cell Physiol 1996;169:159-66.

19 Pastor JC, Calonge M. Epidermal growth factor and corneal wound healing: a multicenter study. Cornea 1992;11:31114.

20 Fredj-Reygrobellet D, Plouet J, Delayre T, et al. Effects of aFGF and bFGF on wound healing in rabbit corneas. Curr Eye Res 1987;6:1205-9.

21 Lemp MA. Report of the National Eye Institute/Industry Workshop on Clinical Trials in Dry Eyes. CLAO $\mathcal{F}$ 1995;21:221-32.

22 Nakamura M, Nishida T, Mishima $\mathrm{H}$, et al. Effects of antimicrobials on corneal epithelial migration. Curr Eye Res 1993;12:733-40

23 Berry M, Gurung A, Easty DL. Toxicity of antibiotics and antifungals on cultured human corneal cells: effect of mixing, exposure and concentrations. Eye 1995;9:110-15.

24 Daniels JT, Harris IR, Kearney JN, et al. Calcium: a crucial consideration in serum-free keratinocyte culture. Exp Dermatol 1995;4:183-91.

25 Nelson JD, Drake MM, Brewer JT, et al. Evaluation of a physiological tear substitute in patients with keratoconphysiological tear substitute in patients with keratoconjunctivitis sicca. In: Sullivan DA, ed. Lacrimal gland, tear film, and $453-7$.

26 Kirschner SE. Persistent corneal ulcers. What to do when ulcers won't heal. Vet Clin N Am Small Anim Pract 1990;20: 627

27 Collins MK, Perkins GR, Rodriguez Tarduchy G, et al. Growth factors as survival factors: regulation of apoptosis. Bioessays 1994;16:133-8.

28 Rodeck U, Jost M, Kari C, et al. EGF-R dependent regulation of keratinocyte survival. f Cell Sci 1997;110:113-21.

29 Berman MB. Collagenase inhibitors: rationale for their use in treating corneal ulceration. Int Ophthalmol Clin 1975;15: 49-66.

30 Pasternak AS, Miller WM. First-order toxicity assays for eye irritation using cell lines: parameters that affect in vitro irritation using cell lines: parameters that affect

31 Wang XM. A new microcellular cytotoxicity test based on calcein AM release. Human Immunol 1993;37:264-70. 
32 Avisar R, Creter D, Levinsky H, et al. Comparative study of tear substitutes and their immediate effect on the precorneal tear film. Isr Med Sci 1997,33:194-7.

33 Gobbels M, Spitznas M. Corneal epithelial permeability of dry eyes before and after treatment with artificial tears. Ophthalmology 1992;99:873-8.

34 Burstein NL. The effects of topical drugs and preservatives on the tears and corneal epithelium in dry eye. Trans $O p h-$ thalmol Soc UK 1985;104(Pt 4):402-9.
35 Ubbels JL, Williams KK, Lopez Bernal D, et al. Evaluation of effects of a physiologic artificial tear on the corneal epithelial barrier: lectrical resistance and carboxyfluorescein permeability. In: Sullivan DA, ed. Lacrimal gland, tear film, 52 .

36 McDonnell PJ, Schanzlin DJ, Rao NA. Immunoglobulin deposition in the cornea after application of autologous serum. Arch Ophthalmol 1988;106:1423-5.

\section{What's in the next issue}

\section{Future content}

See which articles have just been accepted for publication and preview the table of contents for the next issue a month before it is published

www.bjophthalmol.com 